\title{
Assessment of Hormone Status and Its Correlation with Milk Production during Different Stages of Lactation in Indigenous and Crossbred Cows
}

\author{
M. Surya Prakash ${ }^{1}$, J.S. Arya ${ }^{2}$, P.M. Lunagariya ${ }^{3}$ and M.M. Pathan ${ }^{1 *}$ \\ ${ }^{1}$ Department of Veterinary Physiology and Biochemistry, College of Veterinary Science and \\ Animal Husbandry, Anand Agricultural University, Anand, Gujarat, India \\ ${ }^{2}$ Aravalli College of Veterinary Science and Animal Husbandry, Rajasthan Agricultural \\ University, Sikar, Rajasthan, India \\ ${ }^{3}$ Livestock Research Station, College of Veterinary Science and Animal Husbandry, \\ Anand Agricultural University, Anand, Gujarat, India \\ *Corresponding author
}

\section{A B S T R A C T}

\begin{tabular}{|c|}
\hline Keywords \\
\hline $\begin{array}{l}\text { Cattle, Correlation, } \\
\text { Hormone, } \\
\text { Lactation, Milk } \\
\text { production }\end{array}$ \\
\hline Article Info \\
\hline $\begin{array}{l}\text { Accepted: } \\
30 \text { March } 2018 \\
\text { Available Online: } \\
10 \text { April } 2018\end{array}$ \\
\hline
\end{tabular}

\section{Introduction}

The physiology of lactation includes development of the mammary gland from the fetal to the adult stages, further development during pregnancy and onset of lactation, with the accompanying metabolic and behavioral adaptation. The onset of lactation is accompanied by increase in the blood volume, cardiac output, mammary blood flow, and blood flow through the GI-tract and liver, aiming to provide the udder with nutrient and hormones for regulation of milk synthesis
The study was undertaken to determine and compare the activity of important enzymes and its correlation with milk production in cattle. The study was done on each of six Gir, Kankrej and Crossbred cattle. The animals were divided in to three groups viz. 0-90 days of lactation (Group I), 91-180 days of lactation (group II) and 181 till dry stage (group III). Blood was collected aseptically before and after milking and clear plasma was separated and stored until analyzed. The samples were analysed for endocrine parameters by RIA and IRMA method. Hormone levels were differed significantly between different breeds. Level of Insulin, and Prolactin were higher in Gir, whereas, Kankrej found with highest level of $\mathrm{T}_{3}$ and crossbred found with high concentration of cortisol. Hormone levels of $\mathrm{T}_{3}$ studied found negative correlation with milk yield.

(Bhoite and Padekar, 2002). Food intake and distribution of nutrients of the mammary gland are partially regulated by hormones as well as the repartitioning of nutrient away from the body store towards the udder. Lactation has a great impact on intensity of metabolism and on metabolic parameters (Talvelkar et al., 2008).

Stages of lactation, and production levels, affect the blood metabolic parameters (Berry et al., 2005). Milking and suckling stimuli also induce release of several hormones and 
growth factors (e.g. prolactin, insulin, $\mathrm{GH}$, IGF-I, ACTH, and cortisol) and increase in their release, is fundamental to continuous milk synthesis. Consequently, it is important to understand the relationship among these hormones and growth factors during suckling or hand milking and machine milking, because different modes of milk removal cause different levels of stimulation and thus results in release of different levels/quantity of endocrine profiles. Repeated emptying of udder during, calf suckling stimulates lactogenesis, which appears to increase the flow of dietary nutrients, and this is reflected in blood levels of hormones.

In the dairy cow there is a diminished rate of insulin secretion during lactation. The low insulin concentration would then be of value in allowing mobilization of endogenous energy sources in the form of amino acids and non-esterified fatty acids. (Lomax et al., 1978)

The circulating insulin and thyroxine were correlated positively with stage of lactation and negatively with dairy milk yield (Walsh et al., 1980). Insulin and $\mathrm{T}_{3}$ aid in the process of partitioning of nutrient in milk towards milk production by reducing the demand for nutrients by the peripheral tissue (Jindal and Ludri 1994).

There is also paucity of literature regarding the detailed hormonal values of Gir, and Kankrej cattle at different stages of lactation. Keeping in view the above points, the present study was undertaken in Gir, Kankrej and Crossbred cattle to determine the activity of the hormones in blood plasma, the changes in hormones levels before and after milking, their correlation to milk production and to apply systematic health monitoring and the animal breeding status in order to identify changes that occur as a consequence of pathological processes and changes in the metabolic status in good time.

\section{Materials and Methods}

The research was approved by the Institutional Animal Ethics Committee (IAEC, No.: 179/VPY/2014). The study was carried out on six each of Indigenous Gir, Kankrej and Crossbred cattle maintained at the Livestock Research Station, Anand Agricultural University, Anand, Gujarat. Female cattle of various ages, party and Lactation stages were used, The animals were divided in to three groups viz. 0-90 days of lactation (Group I), 91-180 days of lactation (group II) and 181 till dry stage (group III). The animals were maintained under standard feeding and management conditions followed at Livestock Research Station, Anand Agricultural University, Anand, Gujarat. In Gir and Kankrej, the practise of suckling and hand milking was followed and in crossbred it was weaning and machine milking.

Blood collection was conducted during the months of July 2014 to April 2015. Blood was collected aseptically, between $0600 \mathrm{hrs}$ to $0800 \mathrm{hrs}$ of the day, 20 minutes before milking (B.M) and within 5 minutes after completion of milking (A.F), through the jugular vein. Ten $\mathrm{ml}$ blood was collected in a single venipucture in Lithium Heparin vacutainer. Blood was centrifuged at 3000 RPM for 20 minutes and clear plasma was separated for the estimation of hormones. The samples were analysed for endocrine parameters at the Reproductive Biology Research Unit, College of Veterinary Science \& A. H., A.A.U., Anand by RIA(for plasma tri-iodothyronine, thyroxine and cortisol) and Immuno Radiometric Assay (IRMA method for plasma insulin and prolactin) using the Kits manufactured by Immunotech, Beckman Coulter, Czech Republic.

The data obtained in the present study were subjected to statistical analyses by using BASIC (Beginners All purpose Symbolic 
Instructional Code) programme of the computer and applying the Factorial Completely Randomised Design (CRD) as per Snedecor and Cochran (1990).

\section{Results and Discussion}

The Plasma tri-iodothyronine and thyroxine levels increased significantly along with the progress of lactation in before and after milking in both Gir and Crossbred cows whereas, in kankrej cows thyroxine was only hormone showed significant increase. In each lactation stage a non-significant differences ware observed between milking phases.

The levels of Plasma tri-iodothyronine observed in the present study were similar to finding of Ninan Jacob et al., (2012) in indigenous cattle and Sinka et al., (2008) in cross bred cattle. However, as compared to our levels Sharma and Joshi (2006) were reported lower levels in indigenous cattle whereas, higher levels reported by Deshmukh and Mantri (1997) for cross bred cattle.

The overall mean between the breeds and stages of lactation reflect the plasma tri iodo thyronine differed significantly among the breeds $(\mathrm{P} \leq 0.05)$ with Kankrej recording highest values (2.11 \pm 0.08$)$, followed by cross bred cattle (1.77 \pm 0.06$)$ and Gir (1.74 \pm 0.06$)$ which are at par.

The plasma tri iodo thyronine differed significantly $(\mathrm{P} \leq 0.05)$ among the stages with least value in stage-I $(1.73 \pm 0.08)$ followed by stage-II $(1.88 \pm 0.07)$ which are at par and highest values in stage-III $(2.01 \pm 0.09)$.

When the overall mean between the breeds and stages of lactation were compared it was observed a non-significant variation in the plasma thyroxine levels among the breeds, with cross bred cattle recording highest values (66.16 \pm 4.68$)$ followed by Kankrej (65.36 \pm
4.36) and Gir cows $(61.53 \pm 5.43)$. The plasma thyroxine differed significantly among the stages $(\mathrm{P} \leq 0.05)$ with least value in stage-I $(48.53 \pm 6.63)$, followed by stage-II $(70.58 \pm$ 7.72) and highest values in stage-III (73.94 \pm 5.45$)$ which are at par. The plasma thyroxin level increased significantly from Stage I to III in all the three breeds in before milking stage.

A similar effect of increased plasma thyroxin level with progress of lactation was observed by Akasha et al., (1987). Sharma and Joshi (2006) while interpreting their data suggested that lower thyroxine of plasma was associated with higher lactational performance, possibly due to greater utilization of plasma $T_{4}$ in higher producers. The levels of plasma thyroxine observed in the present study were more than that reported by Sharma et al., (2009) in indigenous cattle and Deshmukh and Mantri (1997) for cross bred cattle. The similar results were also found by Ninan Jacob (2012) for indigenous cattle and by Sinka et.al. (2008) for cross bred cattle. The values observed in present study were lower than those reported by Ali et al., (2011) and Sharma and Joshi (2006) in indigenous cattle.

An important role of the thyroid hormones ( $\mathrm{T}_{3}$ \& $\mathrm{T}_{4}$ ) is observed in the normal body metabolism influencing all the catabolic and anabolic processes (Rudas and Pethes, 1990), which could also explain the higher levels seen in the late lactation stages in our study. The variation in the findings of our study and that of other scientists could be due to the breed, age and nutritional status of the animals. The varying levels of thyroid hormones during different periods of lactation in were a pointer towards its essential role in lactation. Thyroid hormones influence milk synthesis as well as intensity and duration of milk synthesis and are necessary for the maintenance of lactation (Park and Lindberg, 2005) (Table 1 and 2). 
Table.1 Plasma hormone levels at different stages of lactation in indigenous and crossbred cattle (Mean \pm S.E.)

\begin{tabular}{|c|c|c|c|c|c|c|c|c|}
\hline \multirow[t]{3}{*}{ Parameter } & \multirow[t]{3}{*}{ Breed } & \multicolumn{6}{|c|}{ Stages of Lactation } & \multirow{3}{*}{$\begin{array}{l}\text { Overall } \\
\text { mean }\end{array}$} \\
\hline & & \multicolumn{2}{|c|}{ I } & \multicolumn{2}{|c|}{ II } & \multicolumn{2}{|c|}{ III } & \\
\hline & & BM & $\mathbf{A F}$ & $\mathbf{B M}$ & $\mathbf{A F}$ & $\mathbf{B M}$ & $\mathbf{A F}$ & \\
\hline \multirow[t]{4}{*}{$\mathbf{T}_{3}$} & Gir & $1.56^{\mathrm{b}} \pm 0.07$ & $1.54^{\mathrm{f}} \pm 0.05$ & $1.75^{\mathrm{ab}} \pm 0.07$ & $1.75^{\mathrm{e}} \pm 0.07$ & $1.94^{\mathrm{a}} \pm 0.04$ & $1.90^{\mathrm{d}} \pm 0.04$ & $1.74^{\mathrm{t}} \pm 0.06$ \\
\hline & Kankrej & $2.02 \pm 0.04$ & $2.02 \pm 0.03$ & $2.18 \pm 0.07$ & $2.08 \pm 0.05$ & $2.27 \pm 0.11$ & $2.11 \pm 0.15$ & $2.11^{\mathrm{s}} \pm 0.08$ \\
\hline & Cross bred & $1.64^{\circ} \pm 0.01$ & $1.58^{\mathrm{q}} \pm 0.04$ & $1.79^{\mathrm{n}} \pm 0.03$ & $1.78^{p} \pm 0.02$ & $1.93^{\mathrm{m}} \pm 0.02$ & $1.89^{\mathrm{p}} \pm 0.02$ & $1.77^{t} \pm 0.06$ \\
\hline & Overall Mean & \multicolumn{2}{|c|}{$1.73^{\mathrm{w}} \pm 0.08$} & \multicolumn{2}{|c|}{$1.88^{w} \pm 0.07$} & \multicolumn{2}{|c|}{$2.01^{v} \pm 0.09$} & \\
\hline \multirow{4}{*}{$\mathbf{T}_{4}$} & Gir & $44.14^{b} \pm 6.12$ & $44.27^{\mathrm{e}} \pm 5.51$ & $65.79^{a} \pm 5.59$ & $74.36^{\mathrm{d}} \pm 3.34$ & $80.24^{\mathrm{a}} \pm 2.43$ & $60.36^{\mathrm{de}} \pm 8.91$ & $61.53 \pm 5.43$ \\
\hline & Kankrej & $55.54^{\mathrm{i}} \pm 1.75$ & $50.21^{1} \pm 5.21$ & $67.81^{\mathrm{h}} \pm 1.95$ & $78.35^{\mathrm{j}} \pm 3.06$ & $81.23^{\mathrm{g}} \pm 3.48$ & $59.07^{\mathrm{k}} \pm 10.06$ & $65.36 \pm 4.36$ \\
\hline & Cross bred & $48.46^{\mathrm{n}} \pm 6.18$ & $48.58^{\mathrm{r}} \pm 5.83$ & $63.72^{n} \pm 4.47$ & $71.44^{\mathrm{q}} \pm 6.75$ & $86.68^{\mathrm{m}} \pm 2.52$ & $76.09^{p} \pm 4.40$ & $66.16 \pm 4.68$ \\
\hline & Overall Mean & \multicolumn{2}{|c|}{$48.53^{w} \pm 6.63$} & \multicolumn{2}{|c|}{$\mathbf{7 0 . 5 8}^{\mathrm{v}} \pm 7.72$} & \multicolumn{2}{|c|}{$73.94^{\mathrm{v}} \pm 5.45$} & \\
\hline \multirow[t]{4}{*}{ Insulin } & Gir & $44.14^{b} \pm 6.12$ & $44.27^{\mathrm{e}} \pm 5.51$ & $65.79^{a} \pm 5.59$ & $74.36^{\mathrm{d}} \pm 3.34$ & $80.24^{\mathrm{a}} \pm 2.43$ & $60.36^{\mathrm{de}} \pm 8.91$ & $61.53 \pm 5.43$ \\
\hline & Kankrej & $55.54^{\mathrm{i}} \pm 1.75$ & $50.21^{1} \pm 5.21$ & $67.81^{\mathrm{h}} \pm 1.95$ & $78.35^{\mathrm{j}} \pm 3.06$ & $81.23^{\mathrm{g}} \pm 3.48$ & $59.07^{\mathrm{k}} \pm 10.06$ & $65.36 \pm 4.36$ \\
\hline & Cross bred & $48.46^{\mathrm{n}} \pm 6.18$ & $48.58^{\mathrm{r}} \pm 5.83$ & $63.72^{n} \pm 4.47$ & $71.44^{\mathrm{q}} \pm 6.75$ & $86.68^{\mathrm{m}} \pm 2.52$ & $76.09^{p} \pm 4.40$ & $66.16 \pm 4.68$ \\
\hline & Overall Mean & \multicolumn{2}{|c|}{$48.53^{w} \pm 6.63$} & \multicolumn{2}{|c|}{$\mathbf{7 0 . 5 8}^{\mathrm{v}} \pm 7.72$} & \multicolumn{2}{|c|}{$73.94^{\mathrm{v}} \pm 5.45$} & \\
\hline \multirow[t]{4}{*}{ Cortisol } & Gir & $5.00^{b} \pm 0.38$ & $5.53^{\mathrm{e}} \pm 0.48$ & $7.29^{a} \pm 0.36$ & $7.51^{\mathrm{d}} \pm 0.35$ & $5.69^{\mathrm{ab}} \pm 0.45$ & $6.75^{\mathrm{de}} \pm 0.20$ & $6.29^{t} \pm 0.96$ \\
\hline & Kankrej & $5.57^{\mathrm{i}} \pm 0.16$ & $8.64^{\mathrm{j}} \pm 0.15$ & $6.57^{\mathrm{h}} \pm 0.17$ & $7.63^{1} \pm 1.09$ & $7.29^{\mathrm{g}} \pm 0.15$ & $7.44^{\mathrm{j}} \pm 0.19$ & $6.48^{t} \pm 0.69$ \\
\hline & Cross bred & $7.11 \pm 0.10$ & $7.22 \pm 0.07$ & $7.13 \pm 0.20$ & $7.77 \pm 0.18$ & $7.18 \pm 0.18$ & $9.36 \pm 0.18$ & $7.30^{\mathrm{s}} \pm 088$ \\
\hline & Overall mean & \multicolumn{2}{|c|}{$6.13^{w} \pm 0.69$} & \multicolumn{2}{|c|}{$6.99^{\vee} \pm 0.83$} & \multicolumn{2}{|c|}{$6.95^{v} \pm 0.69$} & \\
\hline \multirow[t]{5}{*}{ Prolactin } & Gir & $48.64^{\mathrm{a}} \pm 1.00$ & $49.04^{\mathrm{d}} \pm 1.24$ & $35.92^{c} \pm 1.56$ & $44.40^{\mathrm{e}} \pm 1.38$ & $37.32^{\mathrm{b}} \pm 1.16$ & $38.80^{\mathrm{e}} \pm 0.72$ & $42.36^{\mathrm{s}} \pm 2.01$ \\
\hline & Kankrej & $42.08^{\mathrm{g}} \pm 1.01$ & $49.08^{j} \pm 1.56$ & $34.04^{\mathrm{h}} \pm 0.92$ & $43.12^{\mathrm{k}} \pm 0.96$ & $31.00^{\mathrm{i}} \pm 0.88$ & $34.60^{\mathrm{k}} \pm 0.87$ & $39.80^{t} \pm 1.86$ \\
\hline & Cross bred & $28.20^{\mathrm{m}} \pm 1.00$ & $35.44^{\mathrm{p}} \pm 1.09$ & $26.00^{\mathrm{n}} \pm 1.20$ & $28.80^{\mathrm{q}} \pm 1.23$ & $27.40^{\mathrm{n}} \pm 1.36$ & $28.88^{\mathrm{q}} \pm 1.56$ & $29.00^{u} \pm 1.37$ \\
\hline & Overall mean & \multicolumn{2}{|c|}{$42.64^{\mathrm{v}} \pm 2.04$} & \multicolumn{2}{|c|}{$35.36^{\mathrm{w}} \pm 1.46$} & \multicolumn{2}{|c|}{$33.16^{\mathrm{x}} \pm 1.03$} & \\
\hline & \multicolumn{7}{|c|}{ 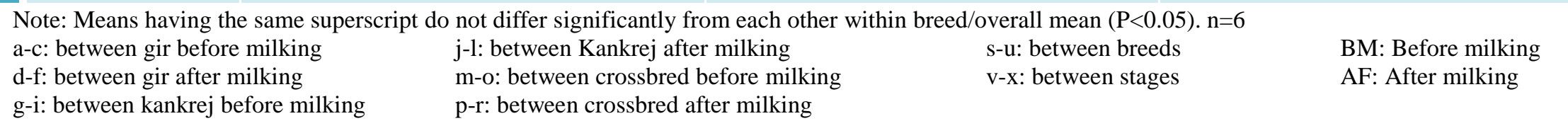 } & \\
\hline
\end{tabular}


Table. 2 Correlation between the hormones and milk yield in Gir, Kankrej and Crossbred cows

\begin{tabular}{|l|c|c|c|c|c|}
\hline & $\mathrm{T} 3$ & $\mathrm{~T} 4$ & cortisol & insulin & prolactin \\
\hline Gir & $-0.502 \pm 0.98$ & $-0.293 \pm 0.52$ & $-0.436 \pm 0.87$ & $-0.262 \pm 0.44$ & $0.364 \pm 0.78$ \\
\hline Kankrej & $-0.487 \pm 0.89$ & $-0.308 \pm 0.98$ & $-0.426 \pm 0.62$ & $-0.242 \pm 0.33$ & $0.354 \pm 0.67$ \\
\hline Cross bred & $-0.442 \pm 0.18$ & $-0.269 \pm 0.79$ & $-0.394 \pm 0.87$ & $-0.303 \pm 0.49$ & $0.402 \pm 0.56$ \\
\hline
\end{tabular}

The higher levels of these hormones in both Gir cattle and crossbred cattle during the $2^{\text {nd }}$ and $3^{\text {rd }}$ stage of lactation reflect the highest metabolic activity of the mammary gland for milk synthesis. It is proved by the fact that peak daily milk yield in both the breeds is reached during second month of lactation (Singh et al., 1996). Thyroid hormones are considered to be essential to counter balance the threat in terms of metabolism and energy requirement for the survival and maintenance of the animals (Jacobs et al., 1981).

The Plasma insulin levels increased significantly from stage-I to stage -II, followed by reduction at stage-III in both milking phases of all the three breeds. We also observed that the milking phases have non-significant differences. However, significant $(\mathrm{P} \leq 0.05)$ difference was observed between lactation stage, with levels in after milking being higher than the before milking phase. Our findings were similar to the results obtained by Ninan Jacob (2012) in indigenous cattle and by Basoglu et al., (1998) in cross bred cattle. However, higher levels were recorded by Sartin et al., (1998), than those observed in the present study. The overall mean, between the breeds and stages of lactation differed significantly $(\mathrm{P} \leq 0.05)$ among the breeds with Gir cows recording highest values $(12.72 \pm 0.89)$ followed by crossbred (11.69 \pm 0.72$)$ and Kankrej cattle (10.17 \pm 0.98). The plasma insulin levels differed significantly $(\mathrm{P} \leq 0.05)$ among the stages of lactation with increase in values from $11.20 \pm 0.85$ (stage-I) to $13.90 \pm 0.96$ (stage-II) followed by a decrease to $9.48 \pm$ 0.69 (stage-III).
During lactation, insulin helps in partitioning of nutrients towards milk production by reducing the demand of peripheral tissues and also sparing glucose for synthesis of lactose for milk production. Increased levels of lactose are responsible for increased milk volume (Jindal and Ludri, 1994). Low level of insulin at stage-I than stage-II could reduce glucose uptake during early lactation, when lactose synthesis rates at peak.

The Plasma cortisol levels increased significantly from stage-I to stage -II, followed by decrease during stage-III in both milking phases of Gir cows while in kankrej the levels were increased significantly with stage of lactation in both the phases of milking. Non-significant changes were observed for crossbred cows. The values observed in the present study were similar to the findings of Ninan Jacob (2012). However, values were less than that reported by Sartin et al., (1998) and Walsh et al., (1980) in cross bred cattle. The overall cortisol mean, between the breeds and stages of lactation differed significantly $(\mathrm{P} \leq 0.05)$, among the breeds with cross bred cattle recording highest cortisol level $(7.30 \pm 0.88)$ followed by Kankrej $(6.48 \pm 0.69)$ and Gir cows (6.29 \pm 0.96) which were at par. The plasma cortisol levels differed significantly $(\mathrm{P} \leq 0.05)$ among the stages with increase in values from $6.13 \pm 0.69$ (stage-I) to $6.99 \pm 0.83$ (stage-II) followed by decrease to $6.95 \pm 0.69$ (stage III). In each stage of lactation, significant $(\mathrm{P} \leq 0.05)$ difference was observed between the milking phases. The values in before milking phase $(6.54 \pm 0.65)$ are lower than the after milking phase $(6.94 \pm 0.59)$. 
Cortisol plays an important role for the internal defense during stressful situations and helps to maintain homeostasis. In severe stress, excessive cortisol secretion reduces the number of lymphocytes, and thus, reduces secretion of immunoglobulins (Martin and Crump, 2003). Highest level of cortisol at stage II as compared to stage I and stage III of lactation justifies the gluconeogenic effect of cortisol for higher level of glucose, which is essential for lactose synthesis. Cortisol is a lactogenic hormone which influences the formation of casein proteins and whey proteins (Park and Lindberg, 2005).

The Plasma prolactin level decreased significantly from stage-I to stage-III, in both milking phases of Gir and kankrej cows, while it was increased significantly in stage III in before milking phase of cross bred cows. Whereas, non-significant changes were observed in after milking phase. Values in before milking phase $(34.56 \pm 1.06)$ are significantly $(\mathrm{P} \leq 0.05)$ lower than the after milking phase $(39.56 \pm 1.86)$ indicating that, suckling and milking are potent stimulants for high circulatory prolactin levels, which is in conformity with the findings of Arya, (1990). The Mean levels of plasma prolactin observed in the present study were similar to the findings of Negrao and Marnet (2002) in cross bred cattle, while it was lower than the values reported by Jacquemet and prigge, (1991).

When the overall mean values, between the breeds and stages of lactation were compared, it was observed that the plasma prolactin level differed significantly $(\mathrm{P} \leq 0.05)$ among the breeds with Gir cattle reporting highest values $(42.36 \pm 2.01)$ followed by Kankrej (39.8 \pm 1.86) and cross bred cattle $(29.00 \pm 1.37)$. The plasma prolactin levels differed significantly $(\mathrm{P} \leq 0.05)$ among the stages with highest values in stage-I $(42.64 \pm 2.04)$ followed by stage-II (35.36 \pm 1.46$)$ and lowest value in
stage-III (33.16 \pm 1.03$)$. The circulating prolactin levels were not correlated with either stage of lactation or milk yield, indicating that the prolactin may be relatively less important for galactopoesis in cow.

Prolactin plays role in mammogenesis and lactogenesis in cattle, enabling the mammary cells to differentiate fully at parturition and initiating the onset of copious milk secretion. Milking or suckling induces release of prolactin and this release declines as lactation advances (Beck et al., 1979), which is similar to findings in the present study. Prolactin in plasma appears to reflect directly the needs of mammary gland cells to stimulate metabolic process in milk secretion (Akasha et al., 1987). The role of prolactin in galactopoesis and its relationship with milk production is not yet established. The blockage of prolactin after establishment of lactation is found not to effect the subsequent lactation, and even exogenous administration of prolactin does not increase the milk yield (Jacquemet and Prigge, 1991).

The negative correlation of $\mathrm{T}_{3}, \mathrm{~T}_{4}$ and insulin with milk yield observed in this study (Table 2) was similar to the findings of Jindal and Ludri, (1994), Deshmukh and Mantri (1997), and Walsh et al., (1980). Whereas, negative correlation of cortisol with milk yield was similar to the findings of Fukasawa et al., (2008). The circulating prolactin correlated with milk yield only during stage-I in Gir, while no correlation was observed in other stages and breeds.

Hormone levels were differed significantly between different breeds. Level of Insulin, and Prolactin were higher in Gir, whereas, Kankrej found with highest level of $\mathrm{T}_{3}$ and crossbred found with high concentration of cortisol. All the hormones having significant differences during different lactation stages. Hormone levels of $\mathrm{T}_{3}$ and $\mathrm{T}_{4}$ increased while 
prolactin decreased with advancement of lactation. Insulin and cortisol increased between Stage-I and stage-II but remained low in stage-III. Significant differences in cortisol and prolactin levels were observed between both before and after phases of milking too. Both these hormones were significantly higher in after milking samples in all the three breeds. The hormones studied found negative correlation with milk yield.

\section{References}

Akasha, M. A., Anderson, R. R., Ellersieck, $M$ and Nixon, D. A. (1987). Concentration of Thyroid Hormones and Prolactin in Dairy Cattle Serum and Milk at Three Stages of Lactation $J$. Dairy Sci., 70(2): 271-276.

Ali, S., Awasthi, M.K., Khan, J.R., and Tiwari, R.P. (2011). Influence of blood metabolites and metabolic hormones on response and conception in post-partum sahiwal cows after Ovosynch treatment. Indian J. Anim. Sci., 81(7): 665-668.

Arya, J.S. (1990) Prolactin and Hypophysealgonadal functions in Buffaloes. Ph.d thesis. N.D.R.I. Division of dairy cattle physiology. Karnal, India

Basoglu, A., Sevinc, M., Ok, M. and Gokcen, M. (1998). Peri and postparturient concentrations of lipid lipoprotein, Insulin and glucose in normal dairy cows. Turkish J. Vet. Anim. Sci's., 22: 141-144.

Beck, N.F.G., Tucker, H A. and W. D. Oxender. (1979). Mammary arterial and venous concentration of prolactin in lactating cows after milking or administration of thyrotropin releasing hormone or ergocryptine. Endocrinology 104:111.

Berry, D.P., Harris, B.L., Winkelman, A.M., and Montogomerie, W. (2005). Phenotypic associations between traits other than production and longevity in
New Zealand dairy cattle. J. Dairy Sc., 88: 2962-2974.

Bhoite, U.Y. and Padekar, R.N. (2002). Factors affecting milk yield and composition of Gir halfbreds. Indian J. Anim. Res., 36(1): 67-69

Deshmukh, B.T. and Mantri, A. (1997). Thyroid hormones concentration during lactation in cows. Indian J. Anim. Sci., 67(10): 880-881.

Fukasawa, M., Hideharu Tsukuda., TakarniKosako, and Akhihisayamada. (2008). Effect of lactation, stage, season and parity on milk cortisol concentration in Holstein cows. Livestock science.113 (2/3): 280-284.

Jacobs, R.M., Horney, B. and Beiner, L. (1981). Cutaneous response to PHA-M and haematological changes in corticosteroid treated cows. Can. J. Comp. Med., 45: 384.

Jacquemet, N and Prigge, E.C. (1991). Effect of increased post milking prolactin concentrations on lactation, plasma metabolites, and pancreatic hormones in lactating goats. J. Dairy Sci., 74:109114.

Jindal, S.K. and Ludri, R.S. (1994). Relationship between circulating hormones, metabolites and milk yield in lactating crossbred cows and buffaloes. Asian Australasian J. Anim. Sci., 7(2): 239-248.

Lomax, M.A., Baird, G.D., Symonds, H.W., Mallinson, C.B. and Shaw, S.R. (1978). Proc. Nutr. Soc., 37:95.

Martin, P. A. and Crump, M. H (2003). The Adrenal Gland. In McDonalds veterinary endocrinology. $5^{\text {th }}$ edition., Ed. Pineda M.H. and Dooley, M.P. Iowa state press.pp.165-200

Negro, J.A., and P. G. Marnet. (2002). Effect of calf suckling on oxytocin, prolactin, growth hormone and milk yield in cross bred Gir X Holstein cows during 
milking. Reproductive Nuti.Dev.42:373380.

Ninan Jacob. (2012). Haematological, biochemical and endocrine parameters at different ages and Physiological stages in Gir Cattle and Jaffrabadi Buffaloes. Ph.D. Thesis, Anand agricultural university, Anand.

Park, C. S and Lindberg, G. L. (2005). The mammary gland and lactation. In Dukes Physiology of Domestic animals.12 ${ }^{\text {th }}$ edn. Ed. Reece, W.O. Panama Publishing Corporation, New Delhi.P728

Rudas, P. and Pethes, G. (1990). New aspects of thyroid physiology: A review. ActaVeterinaria, Hungarica, 38:77.

Sartin, J.L., Cummins, K.A., Kemppainen, R.J., Cummins, K.A. and Williams J.C. (1998). Plasma concentration of metabolic hormones in high and low producing dairy cows. J. Dairy Sci., 71:650-657.

Sharma, M. C. and Chinmay Joshi. (2006). Haemato-biochemical, vitamin and hormone profile of macro mineral deficient cattle of north-eastern India. Indian Journal of Animal Science. 76(1):727-752
Sharma, M. C., Chinmay Joshi and Gunjan Das. (2009). Soil, fodder and serum mineral (Cattle) and Haematobiochemical profile in some central districts of central Uttar Pradesh. Indian Journal of Animal Science. 79(4):411145.

Singh, S.K., Singh, V.P. and Singh, H.S. (1996). Studies on physiological and biochemical attributes of three breed crossbred cows during estrus. Indian J. Anim. Prod. Mgmt. 12(1):17-19.

Sinka, K., Illek, J., Kumprechtova, D. and Novak, P. (2008). Changes in T3 and T4 plasma concentrations in dairy cows during lactation. Jubilee World Buiatrics Congress, P 283.

Snedecor, G.W. and Cochran, W.G. (1990). Statistical Methods, $8^{\text {th }}$ ed. Iowa State University Press, Iowa, USA.

Talvelkar, B.A., Patil, R. R. Ingole, S. Dand. Bharucha. S.V (2008). Serum enzymatic profile of buffaloes during gestation, lactation and peripartum period. Indian Journal of Animal science. 78 (3):247-250.

Walsh, D.S., Vesely, J.A. and Mahadevan, S. (1980). Relationship between milk production and circulating hormones in dairy cows. J. Dairy Sci., 63: 290-94.

\section{How to cite this article:}

Surya Prakash, M., J.S. Arya, P.M. Lunagariya and Pathan, M.M. 2018. Assessment of Hormone Status and Its Correlation with Milk Production during Different Stages of Lactation in Indigenous and Crossbred Cows. Int.J.Curr.Microbiol.App.Sci. 7(04): 3632-3639. doi: https://doi.org/10.20546/ijcmas.2018.704.409 